Check for updates

Received 17th January 2018

Accepted 8th May 2018

DOI: $10.1039 / \mathrm{c} 8 \mathrm{ra00492g}$

rsc.li/rsc-advances
Cite this: RSC Adv., 2018, 8, 18266

\section{Rapid quantitation of multiple ions released from HeLa cells during emodin induced apoptosis by low-cost capillary electrophoresis with capacitively coupled contactless conductivity detection}

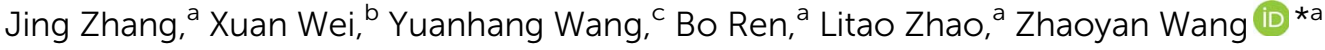
and Qiaosheng $\mathrm{Pu}^{\mathrm{c}}$

Change in cation concentration, including that of potassium and sodium, is characteristic of apoptosis, therefore it is significant to detect cation concentration changes. In this work a rapid, sensitive, and practical method was developed for the determination of $\mathrm{Na}^{+}$and $\mathrm{K}^{+}$concentration in HeLa cells during emodin induced apoptosis by a low-cost capillary electrophoresis device with capacitively coupled contactless conductivity detection $\left(C E-C^{4} D\right)$. Under the optimized conditions, both ions were baseline separated in $4 \mathrm{~min}$ with $40 \mathrm{mM}$ MES/40 mM His containing $1 \mathrm{mM} 18$-crown- 6 as the separation buffer at $\mathrm{pH}$ 6.0. The limit of detections (LODs) and limit of quantifications (LOQs) were $0.47-1.15 \mu \mathrm{M}$ and $1.58-$ $3.86 \mu \mathrm{M}$, respectively. The precision for migration times and peak areas was below $0.56 \%$ and $3.74 \%$, respectively. The data proved that the concentration of cations in cells can be accurately quantified. It was found that the $\mathrm{K}^{+}$concentration decreased from $82.2 \mu \mathrm{M}$ to $52.7 \mu \mathrm{M}$, and the $\mathrm{Na}^{+}$concentration increased from $62.4 \mu \mathrm{M}$ to $127.2 \mu \mathrm{M}$ during the process of apoptosis when the cell density was $1 \times 10^{5}$ cells per $\mathrm{mL}$. The low-cost CE- $\mathrm{C}^{4} \mathrm{D}$ provides a convenient way to decipher the interaction of $\mathrm{Na}^{+}$and $\mathrm{K}^{+}$ in the regulation of cell apoptosis.
\end{abstract}

\section{Introduction}

Apoptosis is a process of programmed cell death which maintains homeostasis and is controlled by genes. ${ }^{1}$ It is essential for the maintenance of embryonic development, immune system function, and tissue homeostasis in multicellular organisms. ${ }^{2-4}$ The deregulation of cell apoptosis leads to many pathological conditions such as cancer, neurodegenerative diseases, atherosclerosis, autoimmune diseases, and viral infection. ${ }^{3,5}$ In recent years, induction of target cell apoptosis has become one of the important mechanisms by which anticancer drugs eliminate precancerous lesions or tumor cells..$^{6-9}$ Therefore apoptosis research, for the purpose of understanding the pathogenesis of disease and treatment, is very important.

Cells undergoing apoptosis generally show characteristic biochemical changes, including cell volume decrease, phosphatidylserine valgus, DNA fragmentation, chromatin condensation, and so on. ${ }^{10}$ Studies have shown that intracellular cation migration plays an important role in the process of apoptosis,

${ }^{a}$ School of Pharmacy, Lanzhou University, Lanzhou 730000, China.E-mail:wangzhy@ lzu.edu.cn

${ }^{b}$ Department of Chemistry, Tonghua Normal University, Tonghua, 134002, China

${ }^{c}$ College of Chemistry and Chemical Engineering, Lanzhou University, Lanzhou 730000, China namely, that a decrease in intracellular potassium concentration can promote apoptosis. Apoptosis is inhibited when $\mathrm{K}^{+}$ efflux is prevented, and the cationic imbalance during apoptosis is accompanied by an increase in $\mathrm{Na}^{+}$concentration and a decrease in $\mathrm{K}^{+}$concentration. ${ }^{11-15}$ The morphological changes in the apoptosis process can be observed directly via microscopy, but the quantitative analysis of cellular ions cannot be performed so easily. Up until now, some techniques have been reported for ion concentration detection in cells, including energy dispersive X-ray microanalysis (EDXMA), ${ }^{16}$ atomic absorption spectroscopy, ${ }^{17,18}$ radioactive ion analogs ${ }^{19}$ nuclear magnetic resonance (NMR), ${ }^{20}$ flow cytometry, ${ }^{11,21}$ and laserinduced fluorescence detection (LIF). ${ }^{22,23}$ These methods have their advantages and disadvantages, such as flow cytometry and microchip electrophoresis with LIF having a high sensitivity and high detection speed, however the cations need to be labelled before analysis due to the lack of chromophore groups, and EDXMA and NMR are expensive and their operation not so convenient. Therefore, a simple and rapid method for the determination of intracellular ion concentration changes in apoptosis is necessary.

Capillary electrophoresis (CE) is an efficient and inexpensive analytical technique that offers an attractive alternative to traditional methods. Capacitively coupled contactless conductivity detection $\left(\mathrm{C}^{4} \mathrm{D}\right)$ is a relatively new approach for ion 
detection, ${ }^{24,25}$ and has been used successfully in the determination of inorganic cations in different kinds of samples. ${ }^{26-31}$ Herein we describe a simple and fast method for the determination of cations in cells at different stages of apoptosis with CE-C ${ }^{4} \mathrm{D}$. The effects of experimental conditions such as $\mathrm{pH}$, concentration of background electrolyte, and separation voltage were systematically investigated with ammonium, potassium, calcium, sodium, and magnesium as model analytes. Under the optimal conditions, the concentrations of $\mathrm{K}^{+}$and $\mathrm{Na}^{+}$in cells were determined successfully, and the reproducibility and precision were found to be satisfactory for the study of the apoptosis process.

\section{Experimental}

\section{Reagents and materials}

Morpholine ethane sulfonic acid (MES, $\geq 99.5 \%$ ) and L-histidine (His, 99\%) were purchased from Aladdin Chemistry Co., Ltd. (Shanghai, China). Ammonium chloride, manganese chloride and sodium hydroxide were obtained from Tianjin Guangfu Science and Technology Development Co., Ltd. (Tianjin, China). Potassium chloride was a product of the Chengdu Union Chemical Reagent Research Institute (Chengdu, China). Anhydrous calcium chloride was obtained from the Tianjin Bodi Chemical Co., Ltd. (Tianjin, China). Sodium chloride was obtained from the Chengdu Kelon Chemical Reagent Plant (Chengdu, China), anhydrous magnesium chloride was a product of the Tianjin Guangfu Fine Chemical Research Institute (Tianjin, China). D-Glucose was purchased from the Xi'an Zhoudingguo Chemical Reagent Factory (Xi'an, China). All reagents were of analytical grade. All solutions were filtered through $0.22 \mu \mathrm{m}$ membranes (Shanghai Xinya Purification Materials Factory, Shanghai, China) and degassed in an ultrasonic bath for $5 \mathrm{~min}$ before use. Deionized water was taken from a Milli-Q water purification system (Millipore) for solution preparation.

RPMI-1640, penicillin-streptomycin, and trypsin were products of GE Healthcare Life Sciences HyClone Laboratories of the United States, and the fetal bovine serum was obtained from Zhejiang Tianhang Biotechnology Co., Ltd. (Zhejiang, China). Emodin was purchased from J\&K Chemical Co. (Beijing, China); it was dissolved in dimethyl sulphoxide (DMSO) at a concentration of $40 \mathrm{mM}$ to form a stock solution, which was then diluted to the final concentration with RPMI 1640 full culture medium when used. 3-(4,5-Dimethyl-thiazol-2-yl)-2,5diphenyltetrazolium bromide (MTT) was obtained from Sigma Chemical Co. (USA). The Annexin V-FITC apoptosis detection kit was obtained from the Beyotime Institute of Biotechnology (Shanghai, China).

\section{Apparatus}

All electropherograms were acquired using a laboratory-made CE device with a capacitively coupled contactless conductivity detector, which contained a HV power module, a DDS signal generator and a laboratory-built low-cost $C^{4} D$ unit (Fig. 1). The electrodes were built in the same way as described by Zhang

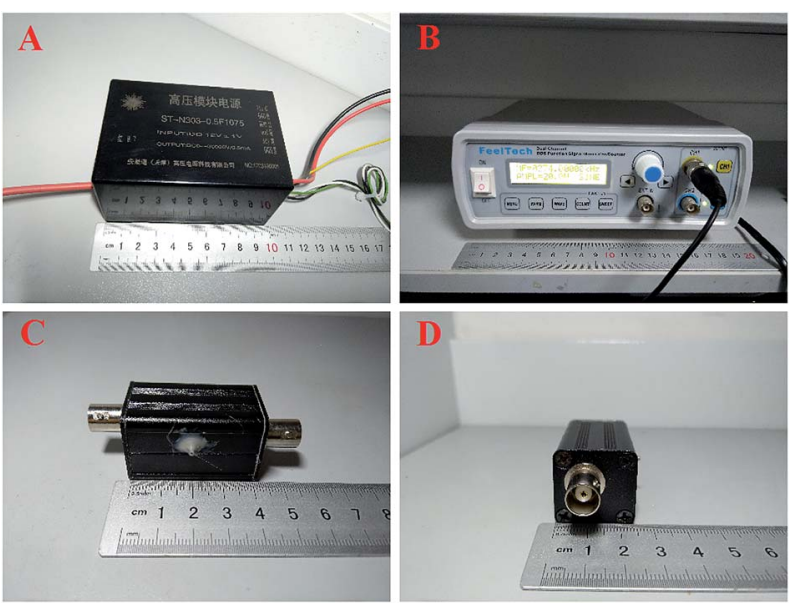

Fig. 1 A schematic illustration of the CE-C $C^{4} D$ system: (A) HV power module; (B) DDS signal generator; (C) and (D) the detection cell.

et $a l .{ }^{32}$, except that a much smaller shielding box $(4.2 \times 2.5 \times$ $2.5 \mathrm{~cm}$ ) was used. All of these parts are small enough to be accommodated on a normal biological research platform. The signal was digitized by a USB-6003 data acquisition card of NI together with the control of the high voltage through a Labview program (National Instruments, Austin, TX, USA). The RT-6100 ELISA analyzer was obtained from Shenzhen Rayto Life Science Co., Ltd (Shenzhen, China) and the flow cytometer was obtained from LSRFortessa (BD Biosciences, San Jose, CA, USA). The H1650-W Centrifuge was purchased from Hunan Xiangyi Laboratory Instrument Development Co., Ltd (Hunan, China).

The fused silica capillary was obtained from Xinnuo Spectrum Co., Ltd (Hebei, China). New fused silica capillaries were conditioned by rinsing with $1 \mathrm{M} \mathrm{NaOH}$ for $30 \mathrm{~min}$, and deionized water for $10 \mathrm{~min}$ prior to first use. Prior to everyday use, the capillary was rinsed with $1 \mathrm{M} \mathrm{NaOH}$ for $10 \mathrm{~min}$, then with deionized water for $5 \mathrm{~min}$, and finally with the background electrolyte (BGE) for $5 \mathrm{~min}$. The fused-silica capillary used in all experiments was $54 \mathrm{~cm}$ long ( $42 \mathrm{~cm}$ to the detector) and had a 50 $\mu \mathrm{m}$ internal diameter; the samples were injected at $1 \mathrm{kV}$ for $10 \mathrm{~s}$, and the volume was about $2.5 \mathrm{~nL}$. In the progress of separation, glass bottles of $1.5 \mathrm{~mL}$ were used as the cathode and anode reservoirs. MES/His was used as the running buffer.

\section{Cell culture}

The human cervical cancer HeLa cells were cultured with RPMI 1640 medium containing $10 \%(\mathrm{v} / \mathrm{v})$ fetal bovine serum, $100 \mathrm{U}$ $\mathrm{mL}^{-1}$ penicillin, and $100 \mu \mathrm{g} \mathrm{mL}^{-1}$ streptomycin. Cells were incubated at $37^{\circ} \mathrm{C}$ in a humidified incubator in an atmosphere of $5 \% \mathrm{CO}_{2}$ and were passaged every 2-3 days.

\section{Preparation of cell lysates}

Firstly, the cells were digested with trypsin, and an appropriate amount of cell culture medium was added and mixed well. The cell suspension was centrifuged at $1000 \mathrm{rpm}$ for $5 \mathrm{~min}$ and the supernatant was discarded, after which the cells were resuspended in $5 \%$ glucose solution and counted. Secondly, the 
cells in the control group and the dosing group were adjusted to the same concentration of $10^{5}$ cells per $\mathrm{ml}$ and then washed three times with $5 \%$ glucose solution to remove the extracellular matrix. After that, $1 \%$ Triton X-100 was added with a volume ratio of $1: 20$ for 10 minutes to complete the cell lysis. Finally, the lysates were centrifuged at $10000 \mathrm{rpm}$ for $8 \mathrm{~min}$, and the supernatant was analysed directly. In order to avoid influence on the determination by other substances in cell, the cell lysates were used as a blank matrix after removal of the cations by electrolysis. Furthermore, in order to eliminate the effect of cations on detection, all of the solutions including the water were electrolyzed to remove the cations.

\section{MTT assay for cell proliferation}

HeLa cells (100 $\mu \mathrm{L}$ of cell suspension per well) in logarithmic phase were seeded into a 96-well plate at $6 \times 10^{4}$ cells per well and incubated at $37{ }^{\circ} \mathrm{C}$ for $24 \mathrm{~h}$. Then they were treated with emodin $(0,60,80,100,120$ and $140 \mu \mathrm{M})$, each for $24 \mathrm{~h}$ and $48 \mathrm{~h}$. Due to the emodin being dissolved in DMSO, in order to eliminate the effect of different concentrations of DMSO on cell proliferation, a certain amount of DMSO was added to ensure each sample remained at the same concentration, when the emodin concentration was lower than $140 \mu \mathrm{M}$. After that, the supernatant medium was removed, and $100 \mu \mathrm{L}$ of culture medium and $20 \mu \mathrm{L}$ of $5 \mathrm{mg} \mathrm{mL} \mathrm{mL}^{-1}$ MT dye were added and cultured for another $4 \mathrm{~h}$. The supernatant was discarded, and purple-colored precipitates of formazan were dissolved in 100 $\mu \mathrm{L}$ of DMSO by gently shaking for $5 \mathrm{~min}$. Finally, the optical density (OD) value at $492 \mathrm{~nm}$ was measured by a microplate reader, and the relative survival rate of cells was calculated from the mean of 6 well OD values. The relative cell survival rate was calculated according to eqn (1), and the error is expressed as the standard deviation (SD).

$$
\frac{\text { OD of experimental group - OD of blank group }}{\text { OD of control group - OD of blank group }} \times 100 \%
$$

\section{Quantification of apoptosis by flow cytometry}

In this experiment, the apoptotic condition was detected by flow cytometry with the Annexin V-FITC apoptosis detection kit. Briefly, two groups of HeLa cells were incubated with $0 \mu \mathrm{M}$ and $100 \mu \mathrm{M}$ of emodin for $24 \mathrm{~h}$ and $48 \mathrm{~h}$, respectively. Then the cells were digested with trypsin and centrifuged to remove the supernatant, and $195 \mu \mathrm{L}$ of Annexin V-FITC binding buffer was added to re-suspend the cells. Then $5 \mu \mathrm{L}$ of Annexin V-FITC staining solution and $10 \mu \mathrm{L}$ of propyl iodide were added, followed by incubation at room temperature for 20 minutes, and analysis by flow cytometry.

\section{Results and discussion}

\section{Cell apoptosis induced by emodin}

HeLa cells were incubated with different concentrations of emodin $(0,60,80,100,120$ and $140 \mu \mathrm{M})$ for $24 \mathrm{~h}$ and $48 \mathrm{~h}$, and the relative viability of cells was determined by an MTT colorimetric assay (Fig. 2). The results show that the relative survival rate of the administered groups were significantly lower than those with an emodin concentration of $0 \mu \mathrm{M}$ (control group), and that when the cell was treated with $100 \mu \mathrm{M}$ emodin for $48 \mathrm{~h}$, the survival rate was suppressed effectively.

In order to further quantitatively determine the apoptotic rate of HeLa cells induced by emodin, $0 \mu \mathrm{M}$ and $100 \mu \mathrm{M}$ emodin was incubated with HeLa cells for $24 \mathrm{~h}$ and $48 \mathrm{~h}$, respectively. After staining with Annexin V-FITC and PI reagent, the cells were analyzed by flow cytometry. From Fig. 3, we found that less than $5 \%$ of the cells were apoptotic in the control group, and that the apoptotic rates of the cells treated with emodin for $48 \mathrm{~h}$ reached $85.9 \%(\mathrm{Q} 2+\mathrm{Q} 4)$. Based on these results, we selected $100 \mu \mathrm{M}$ emodin to induce the apoptosis of HeLa cells with an incubation of $48 \mathrm{~h}$, and used the model to verify the applicability of $C E-C^{4} \mathrm{D}$ in the determination of ion concentration in this process.

\section{Optimization of the CE separation}

Hydrodynamic injection and electrokinetic injection are two common injection methods in CE. With EK injection, a higher signal-to-noise ratio is achieved by preconcentration of the analytes during sample introduction. ${ }^{33}$ In this work, the effects of gravity injection and electrokinetic injection on the separation were examined, and the results showed that the sensitivity is much higher for electrokinetic injection at $1 \mathrm{kV}$ for $10 \mathrm{~s}$, in contrast to gravity injection at $10 \mathrm{~cm}$ for $10 \mathrm{~s}$, therefore electrokinetic injection was adopted. Due to the dependence of the injected amount of analytes on the ionic strength of the sample, internal standards were frequently used to correct the deviation. $\mathrm{Mn}^{2+}$ was selected as the internal standard because normally it does not exist in the cell and can be well resolved from other cations.

The effect of $\mathrm{pH}$ on the separation was examined in the range 3.0-6.0 and acetic acid was used to adjust the pH. With the increase of the buffer $\mathrm{pH}$ value, the separation time became

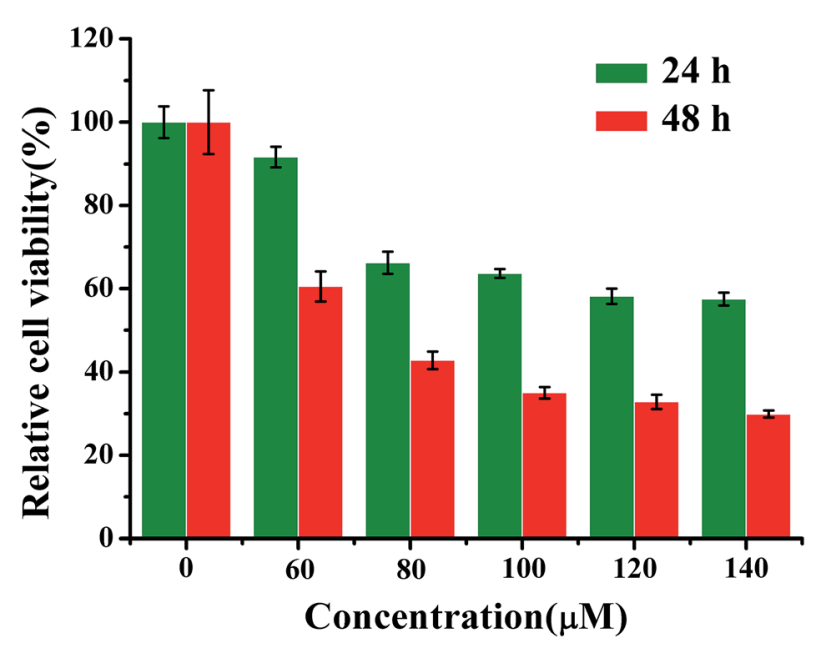

Fig. 2 The relative cell activity was measured via the MTT method at different concentrations and different times after treatment with emodin ( $n=6$, mean value \pm SD). 


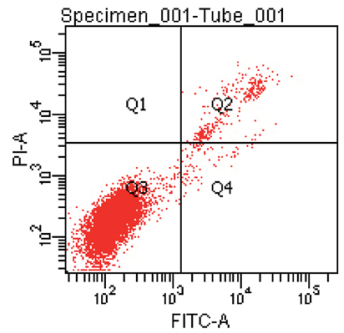

Control

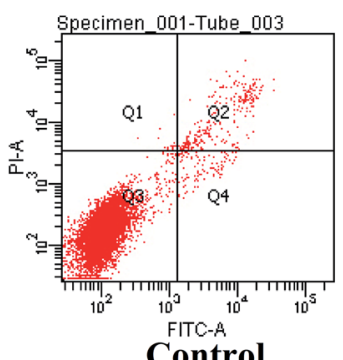

Control

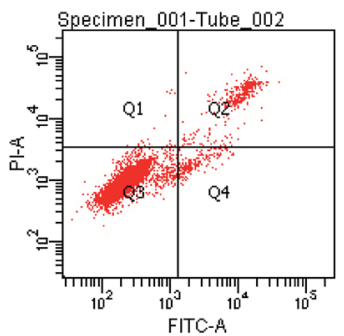

Emodin(24h)

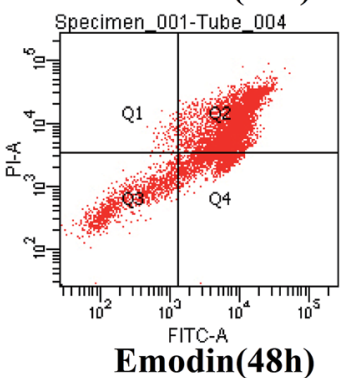

Emodin(48h)
Fig. 3 Emodin-induced apoptosis in HeLa cells was determined by flow cytometry using the Annexin V FITC-PI staining method. Q1 denotes mechanically damaged cells, Q2 denotes late apoptotic cells, Q3 denotes normal cells, and Q4 denotes early apoptotic cells.

shorter, and the separation efficiency was improved (Fig. 4A). At $\mathrm{pH}$ 6.0, all of these cations were baseline separated. Since alkaline solution may introduce cations that would interfere with the ion measurement, a higher $\mathrm{pH}$ was not attempted and pH 6.0 was selected for the following experiment.

The concentration of the electrolyte is important to achieving a good resolution; in this experiment, the influence of the buffer electrolyte concentration was examined in the range 10-80 mM. As shown in Fig. 4B, the migration time of all cations was prolonged with an increase in buffer concentration, which is probably due to the thinner electric double layer with an increase in ionic strength, which decreases the electroosmotic flow, and improves the separation. The best resolution was obtained in $40 \mathrm{mM}$ MES/His. Therefore, $40 \mathrm{mM} \mathrm{MES} / \mathrm{His}$ containing $1 \mathrm{mM}$ 18-crown-6 was selected as the running buffer.

To achieve fast analysis, the influence of running voltage on the separation behaviour was investigated in the range 10-18 $\mathrm{kV}$. The migration speed of all ions is increased and the column efficiency is improved with the increase in separation voltage (Fig. 4C). However, as the highest voltage provided by the power supply module in this experiment is $20 \mathrm{kV}$, for the reliable running with other biological research facilities, a higher voltage was not adopted, and $18 \mathrm{kV}$ was selected for other experiments. Under this condition, all the cations were baseline separated. The resolution between $\mathrm{Ca}^{2+}$ and $\mathrm{Na}^{+}$was 1.52 under the final optimized separation conditions, and that between $\mathrm{Na}^{+}$ and $\mathrm{Mg}^{2+}$ was 1.69 . The analysis takes about $4 \mathrm{~min}$, which is fast enough for monitoring the process for $24 \mathrm{~h}$ or longer. If a shorter capillary is used, the analysis can be quicker.

\section{Performance and application}

A series of different concentrations of sodium and potassium were used as the standard mixture for multiple regression analyses, and all data obtained from the electropherograms are listed in Table 1. Both $\mathrm{K}^{+}$and $\mathrm{Na}^{+}$show a good linear relationship in the range 50-500 $\mu \mathrm{M}$. The intra-day and inter-day relative standard deviations of the peak areas were in the range $1.57-3.74 \%$, and those for the migration time were in the range of $0.48-0.56 \%$. The detection limit $(\mathrm{S} / \mathrm{N}=3)$ of these cations in the blank sample matrix was about $1.2 \mu \mathrm{M}$, and the specific data are presented in Table 1 , and the maximal value of peak-to-peak noise of the baseline is $0.002 \mathrm{mV}$, which is good enough for the measurement of potassium and sodium ions in cell samples.

The method was applied to the determination of the cations in cells during emodin induced apoptosis. As shown in Fig. 5, after $48 \mathrm{~h}$ of incubation with emodin, the potassium ion concentration decreased from $82.2 \mu \mathrm{M}$ to $52.7 \mu \mathrm{M}$, and the sodium ion concentration increased from $62.4 \mu \mathrm{M}$ to $127.2 \mu \mathrm{M}$
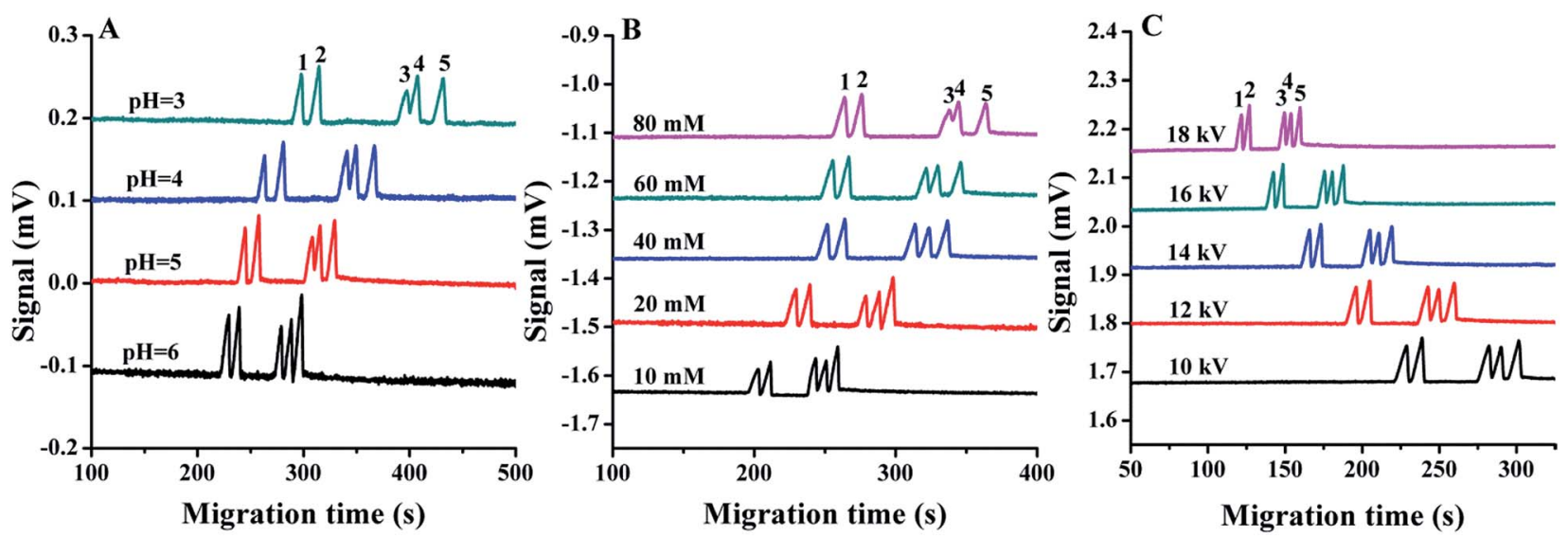

Fig. 4 Effects of buffer $\mathrm{pH}(\mathrm{A})$, electrolyte concentration (B) and separation voltage (C) on separation. Separation conditions, except as otherwise declared: $40 \mathrm{mM} \mathrm{MES} / \mathrm{His}$ containing $1 \mathrm{mM} 18$-crown-6 adjusted to pH 6.0 with acetic acid, except $20 \mathrm{mM}$ MES/His in (A) and the separation voltage was $10 \mathrm{kV}$. The capillary total and effective lengths were 54 and $42 \mathrm{~cm}$, respectively, and the injection voltage was $1 \mathrm{kV}$ for $10 \mathrm{~s}$. Peaks: (1) $\mathrm{NH}_{4}^{+}$, (2) $\mathrm{K}^{+}$, (3) $\mathrm{Ca}^{2+}$, (4) $\mathrm{Na}^{+}$, and (5) $\mathrm{Mg}^{2+}$. 
Table 1 Method validation for the determination of cations with $C E-C^{4} D$

\begin{tabular}{|c|c|c|c|}
\hline \multicolumn{2}{|l|}{ Characteristics } & $\mathrm{K}^{+}$ & $\mathrm{Na}^{+}$ \\
\hline \multicolumn{2}{|l|}{ Regression equation } & $y=0.0351 x-0.0747$ & $y=0.0207 x+0.9831$ \\
\hline \multicolumn{2}{|l|}{$R^{2}$} & 0.996 & 0.993 \\
\hline \multicolumn{2}{|l|}{ LODs $(\mu \mathrm{M})$} & 0.47 & 1.15 \\
\hline \multicolumn{2}{|l|}{ LOQs $(\mu \mathrm{M})$} & 1.58 & 3.86 \\
\hline Intra-day RSD \% $(n=6)$ & Migration time & 0.48 & 0.56 \\
\hline & Peak area & 2.7 & 3.74 \\
\hline
\end{tabular}

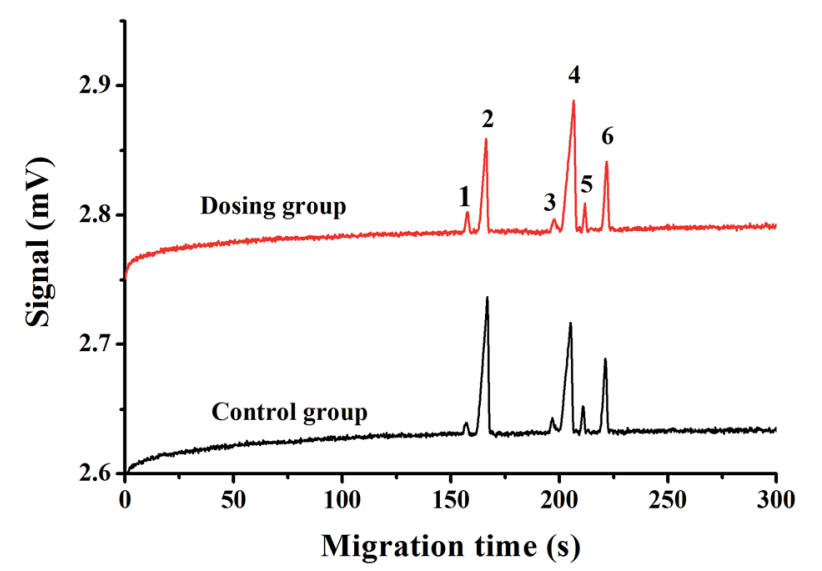

Fig. 5 Electropherogram of cells in the control and dosing groups with a cell density of $10^{5}$ cells per $\mathrm{ml}$. Peak identification: (1) $\mathrm{NH}_{4}{ }^{+}$, (2) $\mathrm{K}^{+}$, (3) $\mathrm{Ca}^{2+}$, (4) $\mathrm{Na}^{+}$, (5) $\mathrm{Mg}^{2+}$, and (6) $\mathrm{Mn}^{2+}$ (internal standard, $200 \mu \mathrm{M}$ ). BGE: $40 \mathrm{mM}$ MES/His containing $1 \mathrm{mM} 18$-crown-6 (pH 6.0), injection voltage: $1 \mathrm{kV}$ for $10 \mathrm{~s}$, separation voltage: $18 \mathrm{kV}$. Other conditions are the same as in Fig. 4.

when the cell density was $1 \times 10^{5}$ cells per $\mathrm{mL}$. At the same time, the concentrations of $\mathrm{NH}_{4}^{+}, \mathrm{Ca}^{2+}$ and $\mathrm{Mg}^{2+}$ in the cells also changed. The results revealed the simultaneous change in concentration of multiple ions during cell apoptosis, which is consistent with previous reports. ${ }^{14,15,34}$

Accordingly, the changes of ions in apoptosis cells can also indicate the state of the cells, and the low cost $\mathrm{CE}-\mathrm{C}^{4} \mathrm{D}$ device used here provides an easy way to monitor ions without the use of any labelling reagents and sophisticated instruments.

\section{Conclusions}

In this paper, an effective and simple method based on low-cost CE-C ${ }^{4} \mathrm{D}$ for the determination of the concentration was established and tested with a model of apoptosis induced by emodin in HeLa cells. The results confirmed a decrease in the concentration of potassium ions and an increase of sodium ions during cell apoptosis. The device is composed of stand-alone parts of a high voltage power supply, a signal generator, and the $\mathrm{C}^{4} \mathrm{D}$ module, and all of them are small - the biggest is the signal generator with a size of $19.0 \times 17.5 \times 7.0 \mathrm{~cm}$, so it can be easily accommodated with a biological platform such as a microscope or a cell culture system. The advantage of a CE based system is the very small sample volume required and the potential for single cell analysis. It can avoid the use of expensive labelling reagents and expensive instruments. The separation is fast, normally within $4 \mathrm{~min}$, so it may be used for on-line monitoring of the change of ions during the whole process, if an automatic sampler is implemented.

\section{Conflicts of interest}

There are no conflicts to declare.

\section{Acknowledgements}

The authors are grateful to the Natural Science Foundation of China (No. 21405067, 21527808, 21575054), the Fundamental Research Funds for the Central Universities (lzujbky-2017-199), and the '13th 5 year Plan' Program of the Jilin Education Department (JJKH20170433KJ).

\section{References}

1 D. L. Vaux and S. J. Korsmeyer, Cell, 1999, 96, 245-254.

2 J. F. R. Kerr, A. H. Wyllie and A. R. Currie, Br. J. Cancer, 1972, 26, 239-257.

3 S. J. Riedl and Y. Shi, Nat. Rev. Mol. Cell Biol., 2004, 5, 897907.

4 M. D. Jacobson, M. Weil and M. C. Raff, Cell, 1997, 88, 347354.

5 H. Okada and T. W. Mak, Nat. Rev. Cancer, 2004, 4, 592-603. 6 S. W. Fesik, Nat. Rev. Cancer, 2005, 5, 876-885.

7 S. Qian, J. Cao, Y. Yan, M. Sun, H. Zhu, Y. Hu, Q. He and B. Yang, Mol. Cell. Biochem., 2010, 345, 13-21.

8 X. Liu, M. Song, Z. Gao, X. Cai, W. Dixon, X. Chen, Y. Cao and H. Xiao, J. Agric. Food Chem., 2016, 64, 7750-7759.

9 G. Wang, T. Zhang, W. Sun, H. Wang, F. Yin, Z. Wang, D. Zuo, M. Sun, Z. Zhou, B. Lin, J. Xu, Y. Hua, H. Li and Z. Cai, Free Radical Biol. Med., 2017, 106, 24-37.

10 C. D. Bortner and J. A. Cidlowski, Pflugers Arch., 2004, 448, 313-318.

11 C. D. Bortner, F. M. Hughes and J. A. Cidlowski, J. Biol. Chem., 1997, 272, 32436-33442.

12 C. D. Bortner and J. A. Cidlowski, J. Biol. Chem., 2003, 278, 39176-39184. 
13 C. D. Bortner and J. A. Cidlowski, Arch. Biochem. Biophys., 2007, 462, 176-188.

14 A. Kondratskyi, K. Kondratska, R. Skryma and N. Prevarskaya, Biochim. Biophys. Acta, 2015, 1848, 25322546.

15 S. P. Yu, L. M. T. Canzoniero and D. W. Choi, Curr. Opin. Cell Biol., 2001, 13, 405-411.

16 I. Z. Nagy, G. Lustyik, V. Z. Nagy, B. Zarandi and C. BertoniFreddari, J. Cell Biol., 1981, 90, 769-777.

17 C. A. Vidair and W. C. Dewey, Radiat. Res., 1986, 105, 187200.

18 V. Yurinskaya, T. Goryachaya, I. Guzhova, A. Moshkov, Y. Rozanov, G. Sakuta, A. Shirokova, E. Shumilina, I. Vassilieva, F. Lang and A. Vereninov, Cell. Physiol. Biochem., 2005, 16, 155-162.

19 R. B. Mikkelsen and C. R. Asher, J. Cell. Physiol., 1990, 144, 216-221.

20 A. M. Castle, R. M. Macnab and R. G. Shulman, J. Biol. Chem., 1986, 261, 3288-3294.

21 C. D. Bortner, M. I. Sifre and J. A. Cidlowski, J. Biol. Chem., 2008, 283, 7219-7229.

22 L. Li, P. Li, J. Fang, Q. Li, H. Xiao, H. Zhou and B. Tang, Anal. Chem., 2015, 87, 6057-6063.
23 L. Li, Y. Fan, Q. Li, R. Sheng, H. Si, J. Fang, L. Tong and B. Tang, Anal. Chem., 2017, 89, 4559-4565.

24 A. J. Zemann, E. Schnell, D. Volgger and G. K. Bonn, Anal. Chem., 1998, 70, 563-567.

25 J. A. Fracassi da Silva and C. L. do Lago, Anal. Chem., 1998, 70, 4339-4343.

26 P. Kubáň, P. Kubáň and V. Kubáň, Electrophoresis, 2002, 23, 3725-3734.

27 P. Tůma, E. Samcová and F. Duška, J. Sep. Sci., 2008, 31, 2260-2264.

28 T. D. Mai and P. C. Hauser, Talanta, 2011, 84, 1228-1233.

29 R. R. Cunha, D. T. Gimenes, R. A. Munoz, C. L. do Lago and E. M. Richter, Electrophoresis, 2013, 34, 1423-1428.

30 J. Sáiz, I. J. Koenka, T. D. Mai, P. C. Hauser and C. GarcíaRuiz, TrAC, Trends Anal. Chem., 2014, 62, 162-172.

31 F. Opekar and P. Tůma, J. Chromatogr. A, 2016, 1446, 158163.

32 M. Zhang, B. N. Stamos, N. Amornthammarong and P. K. Dasgupta, Anal. Chem., 2014, 86, 11538-11546.

33 Z. Krivácsy, A. Gelencsér, J. Hlavay, G. Kiss and Z. Sárvári, J. Chromatogr. A, 1999, 834, 21-44.

34 Y. Jiao, S. Ma, Y. Wang, J. Li, L. Shan, J. Sun and J. Chen, Int. J. Biol. Sci., 2016, 12, 580-593. 